\title{
MUSRENBANG ACARA CEREMONIAL ATAU PENYERAPAN ASPIRASI (Studi Kasus Perencanaan dan Penganggaran Dana Desa di Desa Tegal Arum, Kecamatan Mranggen, Kabupaten Demak, Jawa Tengah)
}

\author{
Moeljono \\ Universitas Semarang \\ sastro.g@gmail.com
}

Diterima: Februari 2019, Disetujui: Maret 2019. Dipublikasikan: April 2019

\begin{abstract}
Ratification of RI Law No. 6/2014 About the Village raises pros and cons, because one of the contents of the Act is a Village Fund Allocation of Rp. 1 Billion. As a consequence villages are required to plan and budget village funds received from the central government. The purpose of this study was to find out how the process along with the planning and budgeting stages of the village in the village of Tegalarum. Mranggen District. Regency of Demak. The researcher wants to evaluate and prove empirically how the practice actually occurs within the scope of the village government regarding the planning and budgeting of the Village Fund Expenditure Budget (APBDes). In addition, this research aims to provide a simple solution to good and correct planning and budgeting processes so that budget goals can be achieved. Research uses a qualitative approach and uses case study methods in analyzing data. The technique used to obtain data is unstructured interviews, observations, and documentation studies.

The research conclusions based on the findings of researchers in the field included several things, namely, the implementation of the Musrenbangdes was only carried out as an annual ceremonial event even though it involved community participation but was false because the Musrenbang remained grounded in the Indicative Ceiling. As a result, the planning proposals that will be made for the Village RPJM, RKPDesa are largely determined by the village head and village officials. The limited human resources in the Village Government can be covered with solid Team Work. Compilation of RKPDes and RAPBDes can be completed on time, but the disbursement of funds from the Regency government is always neglected, so the program that has been determined is always set back. Another interesting finding is that "political autonomy" at the village government level held and controlled by the village head has an impact on village financial management. The impact of course on the use of finance is more centralized
\end{abstract}

Keywords: Musrenbangdes, planning, budgeting, village

\begin{abstract}
Abstrak
Disahkannya UU RI No. 6/2014 Tentang Desa menimbulkan pro dan kontra, karena salah satu isi UU tersebut adanya Alokasi Dana Desa sebesar Rp 1 Milyar. Sebagai konsekwensinya desa dituntut untuk membuat perencanaan dan anggaran dana desa yang diterima dari pemerintah pusat. Tujuan penelitian ini adalah untuk mengetahui bagaimana proses beserta tahap perencanaan dan penganggaran Desa di desa Tegalarum. Kecamatan Mranggen. Kabupaten Demak. Peneliti ingin mengevaluasi dan membuktikan secara empiris bagaimana sebenarnya praktek yang terjadi dalam lingkup pemerintahan desa tentang perencanaan dan pengangaran Anggaran Pendapatan Belanja Dana Desa (APBDes). Selain itu, riset ini bertujuan memberikan solusi sederhana mengenai proses perencanaan dan penganggaran yang baik dan benar sehingga tujuan anggaran bisa tercapai. Penelitian menggunakan pendekatan kualitatif dan menggunakan metode studi kasus dalam menganalisa data. Teknik yang digunakan untuk memperoleh data yakni wawancara tidak terstruktur, observasi, serta studi dokumentasi.

Kesimpulan penelitian berdasarkan temuan peneliti di lapangan mencakup beberapa hal yaitu, pelaksanaan Musrenbangdes hanya dilakukan sebagai acara ceremonial tahunan walau dengan melibatkan partisipasi masyarakat tapi semu karena Musrenbang tetap berpijak pada Pagu Indikatif. Akibatnya, usulan perencanaan yang akan dibuat untuk RPJMDesa, RKPDesa sebagaian besar ditentukan oleh kepala desa dan aparat desa. Keterbatasan SDM pada Pemerintahan Desa dapat tertutupi dengan Team Work yang solid. Penyusunan RKPDes dan RAPBDes dapat selesai tepat waktu, namun pencairan dana dari
\end{abstract}


pemerintah Kabupaten selalu terlabat, sehingga program yang telah ditentukan selalu mengalami kemunduran. Temuan lainnya yang cukup menarik adalah "otonomi politik" di tingkat pemerintah desa yang dipegang dan dikendalikan oleh kepala desa berdampak terhadap manajemen pengelolaan keuangan desa. Dampaknya tentu saja terhadap penggunaan keuangan lebih sentralistik

Kata Kunci: Musrenbangdes, perencanaan, penganggaran, desa

\section{Pendahuluan}

\section{Prolog}

Disahkannya UU No. 6 Tahun 2014 Tentang Desa semakin memperkuat keberadaan desa sebagai bagian dari system pemerintahan. Desa merupakan bagian terkecil dari hirarki pemerintahan pusat dan daerah. Selama lima tahun telah diimplementasikan UU Desa tersebut banyak menuai pro dan kontra akibat besarnya kucuran Dana Desa sebesar 1 Milyar (www.republika.co.id). Pemerintah desa dituntut untuk membuat perencanaan dan penganggaran guna pembangunan desa menjadi mandiri.

Proses Perencanaa dan Penganggaran dalam organisasi sangat penting. Karena dengan perencanaan arah organisasi dapat ditentukan, tidak terkecuali dengan pemerintah desa dimana dalam UU tersebut dinyatakan bahwa dengan adanya dana desa diharapkan agar desa menjadi mandiri. Desa adalah miniatur kota dan kota adalah miniatur Negara, maka apabila desa maju dan mandiri, maka begitu pula Negara akan maju dan mandiri.

Perencanaan dalam penyiapan anggaran sangat penting untuk menentukan jenis kegiatan yang dilakukan di masa datang. Pada level pemerintah daerah, perencanaan dan penganggaran masih banyak masalah. Masalah tersebut dimulai sejak tahapan musyawarah perencanaan dan pembangunan desa, kecamatan forumsatuan perangkat kerja daerah dan musyawarah perencanaan pembangunan kabupaten dilakukan secara seremonial (ceremonial budgeting), (Sopanah, 2012). Dokumen yang sering inkonsisten dalam perencanaan pemerintah daerah adalah RPJMD-RKPD (Burin, 2015; Modesianne, 2016).

Penerapan performance budgeting dalam proses penyusunan anggaran belum berjalan optimal sebagaimana yang diinginkan (Tuasikal, 2010). Partisipasi anggaran (budgetary participaton) berpengaruh terhadap kinerja manajerial dan aparat pemda (Anggraini dan Redy S., 2011; Agusti, 2012; Indriani dan Nadirsyah, 2014; Rahman et al., 2015; Friyanty, 2016). Alokasi anggaran hanya mengutamakan kepentingan politik eksekutif dan legislatif, sehingga ada indikasi partisipasi semu (Hidayati, Sri et al, 2015). Selain itu, Sasaran anggaran yang jelas dalam organisasi dapat berdampak terhadap penyusun anggaran maupun pelaksanaan anggaran (Tresnayani dan Gayatri, 2016). 
Penelitian Wangi dan Ritonga (2010), Subechan et al., (2014), Sutaryo dan Carolina (2014) menjelaskan kurangnya komitmen dalam mentaati jadwal penyusunan APBD, lebih mengutamakan kepentingan dalam pengalokasian anggaran, komposisi DPRD, koordinasi dan komunikasi yang tidak baik, dan kurangnya kompetensi dalam penganggaran dari pihak-pihak yang terlibat dalam penyusunan anggaran menjadi penyebab keterlambatan penetapan APBD pemda. Oleh karena itu, Sjafrizal (2014) dalam (Burin etal, 2015) mengungkapkan bahwa implikasi dari keberhasilan pembangunan daerah tidak bisa dilepaskan dari optimalisasi aspek perencanaan dan penganggaran.

Undang-undang Desa memberikan otonomi penuh kepada desa dalam 4 bidang Sejalan dengan pemberian kewenangan pada UU Desa maka dikuti pula adanya Dana Desa (DD) dari pemerintah pusat melalui Alokasi APBN sebagai sumber pendapatan desa (pasal 72 Ayat 1 poin b). Tentu kewenangan dan alokasi Dana Desa dari pemerintah pusat tersebut menjadi tanggung jawab dan PR bagi aparat desa. Perencanaan yang partisipatif, menyeluruh dan terintegrasi menjadi tugas sekaligus tantangan bagi aparat desa sebagai landasan pengelolaan keuangan yang baik.

Bertambah beratnya tugas kepala desa dan aparat desa dalam hal pengelolaan keuangan desa. Perangkat desa merasa ketakukan dikarenakan akan mengemban amanah yang cukup besar dari sebelumnya, bahkan segala urusan pemerintahan desa akan ditangani dan dilakukan pemeriksaan oleh BPK (Rohimanto, 2015). Pernyataan Pejabat Pemerintah Provinsi Jawa Tengah memperkuat kegelisahaan para kepala desa, paparannya yakni”"

"sampai saat ini sudah ada 900 kepala desa di Jawa Tengah yang dengan intensif di periksa oleh BPK, karena pelaksanaan Dana Desa"

Pernyataan tersebut mengisyaratkan bahwa banyak kepala desa terutama di Jawa Tengah yang tidak siap dengan Dana Desa. Proses pelaksanaan merupakan kesatuan utuh dari proses perencanaan dan penganggaran, walaupun secara akademik bahwa proses penganggaran merupakan salah satu dari perencanaan, sedangkan perencanaan merupakan salah satu fungsi dari manajemen, selain fungsi manajemen yang lain.

Proses perencanaan pada pemerintahan desa adalah terletak pada Musrembangdes. Proses ini sebenarnya untuk menggali potensi dan kelemahan pada masyarakat desa. Karena pemerintah pada tataran diatas desa terkadang tidak tahu potensi dan 
permasalahan yang ada dimasyarakat paling bawah. Namun partisipasi masyarakat sangat kurang, hal ini dikarenakan selama belum adanya UU Tentang desa pembangunan dan pemberdayaan masyarakat dilakukan secara Top Down, selain itu terkadang kepala desa hanya mengakomodasi orang-orangnya . Sehingga masyarakat "setengah hati" dalam mengikuti kegiatan Musrenbangdes untuk Penyusunan RKPDes (Rohmah, 2015). Pengelolaan APBDes dalam Perencanaan Penganggaran belum melibatkan peran masyarakat melalui kegiatan Musyawarah Desa untuk menentukan program kerja yang akan dilaksanakan dari dana APBDes (Surya, 2013).

Transparansi dari manajemen keuangan Desa Kalimo Kecamatan kalianget Kabupaten Sumenep terjadi saat perencanaan saja. Furqani (2010). Dewanti et all.,(2016) perencanaan pengelolaan keuangan Desa Boreng, dalam perencanaan dan penhelolaan keuangan desa menurut Permendagri No. 37/2007 banyak sekali ketidaksesuaiannya. Pada tahap perencanaan terdapat beberapa kecurangan (Fraud). Dachliyati, (2015).

Penelitian dilakukan di desa Tegalarum, Kecamatan Mranggen, Kabupaten Demak. Peneliti hanya memilih satu desa sebagai tempat penelitian dikarenakan peneliti ingin memahami praktik perencanaan dan penganggaran APBDes secara menyeluruh dan komprehensif, disamping itu juga adanya keterbatasan dana penelitian. Desa Tegalarum, dijadikan obyek penelitian karena dana desa terus meningkat tiap tahun dan peneliti memiliki kedekatan dengan beberapa informan yang ada di desa, sehingga bisa membantu peneliti dalam memperoleh data yang riil sesuai dengan yang ada di lapangan.

\section{Pertanyaan Penelitian}

Berbagai masalah yang telah dipaparkan, peneliti mencoba merumuskan masalah apa yang menyebabkan peneliti ingin ketahui. Mengetahui dan mencari hal apa saja yang sebenarnya dirasakan oleh pemerintah desa Tegalarum. Rumusan masalahnya adalah Bagaimana perencanaan dan pengangaran APBDes dilakukan desa Tegalarum, Kecamatan Mranggen, Kabupaten Demak?.

\section{Tujuan Penelitian}

Tujuan penelitian ini adalah untuk mengetahui bagaimana proses dan tahapan perencanaan dan penganggaran Pemerintah Desa di desa Tegalarum, Kecamatan Mranggen, Kabupaten Demak. Peneliti ingin mengevaluasi dan membuktikan secara empiris bagaimana sebenarnya yang terjadi dalam lingkup pemerintahan desa dari sudut 
pemerintah desa itu sendiri tentang perencanaan dan pengangaran APB Dana Desa yang kini peraturannya sudah diubah sesuai dengan UU No 6/2014 tentang Desa. Selain itu, riset ini memberikan solusi sederhana mengenai proses perencanaan dan penganggaran yang baik dan benar sehingga tujuan anggaran bisa tercapai.

\section{Tinjauan Pustaka}

\section{Pemerintah Desa}

Pemerintahan Desa adalah penyelenggaraan urusan pemerintahan dan kepentingan masyarakat setempat dalam sistem pemerintahan Negara Kesatuan Republik Indonesia, sedangkan Pemerintah Desa adalah kepala desa atau yang disebut dengan nama lain dibantu perangkat desa sebagai unsur penyelenggara pemerintahan desa, terkait dengan pengelolaan desa, terdapat beberapa peraturan yang ditetapkan oleh Pemerintah Indonesia sebagai berikut:

a. Undang Undang/UU Nomor 6 Tahun 2014 Tentang Desa

b. Peraturan Pemerintah/ PP Nomor 43 Tahun 2014, mengatur tentang Petunjuk Pelaksanaan atas UU No 6 Tahun 2014 tentang Desa.

c. Peraturan Menteri Dalam Negeri Nomor 113 Tahun 2014, tentang Pengelolaan Keuangan Desa.

\section{Musyawarah Perencanaan Pembangunan Desa}

Musrenbang Desa adalah forum musyawarah tahunan para pemangku kepentingan (stakeholder) desa untuk menyepakati RKP-Desa tahun anggaran yang direncanakan. Setiap desa diamanatkan untuk menyusun dokumen rencana 5 tahunan yaitu RPJM Desa dan dokumen rencana tahunan yaitu RKP Desa. Musrenbang adalah forum perencanaan (program) yang dilaksanakan oleh pemerintah desa, bekerja sama dengan warga dan para pemangku kepentingan lainnya.

Permedagri No 66 tahun 2007, RKP-Desa adalah dokumen perencanaan untuk periode 1 tahun dan merupakan penjabaran dari RPJM-Desa yang memuat rancangan kerangka ekonomi desa, dengan mempertimbangkan kerangka pendanaan yang dimutahirkan, program prioritas pembangunan desa, rencana kerja dan pendanaan serta prakiraan maju, baik yang dilaksanakan langsung oleh pemerintah desa maupun yang 
ditempuh dengan mendorong partisipasi masyarakat dengan mengacu kepada RKPD dan RPJM-Desa.

\section{Penganggaran}

Anggaran adalah suatu rencana terinci yang dinyatakan secara formal dalam ukuran kuantitatif, biasanya dalam satuan uang (perencanaan keuangan) untuk menunjukkan perolehan dan penggunaan sumber-sumber organisasi. Anggaran umumnya dibuat dalam jangka pendek, yaitu untuk durasi waktu satu tahunan atau kurang.

Anggaran adalah estimasi atas penerimaan yang akan diterima dan pengeluaran (biaya) yang akan dikeluarkan terhadap aktivitas yang akan dikerjakan di masa yang akan datang oleh suatu organisasi Kusnadi (1999).

Untuk menyusun suatu anggaran, organisasi harus mengembangkan perencanaan strategis. Melalui perencanaan strategis, anggaran mendapatkan kerangka acuan strategis. Maka anggaran menjadi bermakna sebagai alokasi sumber daya (keuangan) untuk mendanai berbagai program dan kegiatan (strategis).

\section{Metodologi Penelitian}

Penelitian menggunakan pendekatan kualitatif. Dengan pendekatan penelitian kualitatif diharapkan dihasilkan sebuah simpulan yang menjadi sebuah informasi yang berkualitas. Di mana memperhatikan definisi penelitian kualitatif sebagai berikut:

Penelitian kualitatif adalah penelitian yang dilakukan dalam setting tertentu yang ada dalam kehidupan riil (alamiah) dengan maksud menginvestigasi dan memahami fenomena: apa yang terjadi, mengapa terjadi dan bagaimana terjadinya? (Moleong, 2016:44).

Untuk mencapai tujuan penelitian dan memperoleh jawaban atas pengalaman serta pemahaman subyek dalam sebuah situasi dan kondisi yang sedang mereka alami, maka peneliti menggunakan metode studi kasus.

Informan dalam penelitian ini adalah yang memiliki pengalaman langsung tentang perencanaan dan penganggaran desa, dan pihak-pihak yang benar-benar memiliki jabatan dalam struktur pemerintahan desa Tegalarum serta tokoh masyarakat 
Tabel 2.1

Daftar Informan

\begin{tabular}{|c|l|l|l|}
\hline No & \multicolumn{1}{|c|}{ Jabatan } & \multicolumn{1}{|c|}{ Nama } & \multicolumn{1}{|c|}{ Gender } \\
\hline 1 & Kepala Desa & Ali Khadirin & Pria \\
\hline 2 & Sekretaris Desa (plt) & H. Mashudi & Pria \\
\hline 3 & Kasi Pemerintahan dan Operator Desa & Hj, Murtini SH & Wanita \\
\hline 4 & BPD & H. Moh. Sarmin. M. Si & Pria \\
\hline 5 & Tokoh Masyarakat & Kholiq & Pria \\
\hline 6 & Tokoh Masyarakat & Jumari & Pria \\
\hline
\end{tabular}

Sumber : Data Desa Kebon Agung (2019)

Metode pengumpulan data yang digunakan adalah teknik wawancara tidak struktur, observasi dan studi dokumentasi. Wawancara dilakukan dengan mendatangi Kantor dan Rumah Kepala Desa Tegalarum lalu mewawancarai setiap orang yang ada disana. Selain itu, perbincangan lewat media handphone (telepon, SMS dan WA) juga dilakukan jika terdapat hal yang mendesak. Peneliti juga memanfaatkan alat rekam untuk membantu dalam menyusun transkrip wawancara.

Observasi dalam penelitian ini difokuskan untuk mengamati kegiatan seperti Musrenbangdes, penyusunan dokumen perencanaan. Selain itu, observasi dalam penelitian ini dilakukan dengan memperhatikan gerak-gerik tubuh informan saat menjawab pertanyaan oleh peneliti. Setelah itu, studi dokumentasi dilakukan dengan menelaah dokumen-dokumen yang ada seperti RPJMDes, RKPDes, dan APBDesa.

\section{Hasil}

\section{Musrembangdes sebagai Acara "Ceremonial"}

\section{Musrembangdes "Wadah Aspirasi Masyarakat" Bukan"Sekedar Formalitas"}

Musrenbangdes sangat penting dalam proses perencanaan pembangunan desa. Perencanaan dan penganggaran APBDes tentu akan dibahas dan disepakati secara umum lewat Musrenbangdes. Di Desa Tegalarum setiap tahun diadakan Musrenbangdes untuk berkomunikasi dan membahas rencana kerja satu tahun kedepan untuk selanjutnya dianggarkan dalam APBDes. Hal ini sesuai yang diungakapkan oleh Kepala Desa Bapak Ali sebagai berikut:

"Musrenbangdes setiap tahunnya ada, tetapi hanya berbentuk usulan-usulan saja. Usulan- usulannya biasanya dari kepala dusun, ketua RT, Ketua RW, Tomas, PKK dan Karang Taruna yang nantinya akan disampaikan saat musyawarah. 
Penjelasan mengenai setiap tahunnya ada Musrenbangdes diperkuat pemaparan ketua BPD Bapak Moh, Sarmin. M. Si dan Sekdes (Plt) bapak H. Masjudi, sebagai berikut:

"Kalau Musrenbangdes yang diundang kepala dusun, ketua RT, Ketua RW, Tomas, PKK dan Karang Taruna, seluruh unsur masyarakat ada dan terwakili.”

Hasil percakapan dari sebuah wawancara dengan informan menunjukkan bahwa dalam pelaksanaan Musrenbangdes telah memenuhi ketentuan. Sehingga usulan-usulan yang dibutuhkan untuk kemajuan desa bisa tersampaikan dengan baik karena yang hadir mewakili unsur masyarakat.

Kelompok Tani, Karang Taruna. LPM, BPD hadir semua. Kehadiran perwakilan dari semua elemen masyarakat membuat jalannya perencanan yang ada di desa Tegalarum dapat optimal. Sebuah penuturan dari Tokoh Masyarakat Bapak Jumari mengenai Musrenbangdes sebagai berikut:

"Saya selalu diundang dalam perencanaan pembangunan desa mengenai mau dibawa kemana desa ini, potensi, dan tantangan yang dihadapi. Maka sangatlah wajar apabila desa kami mewakili kecamatan Mranggen untuk maju lomba desa tentang evaluasi desa , dan kami yakin bahwa desa kami akan menjadi juara di Kabupaten Demak.”

Sebuah penuturan dari bapak Jumari memberikan bukti bahwa Musrenbangdes telah menyentuh dan melibatkan seluruh elemen masyarakat yang ada di desa Tegalarum. Dari penjelasan diatas tercermin bahwa dalam hal ini pemerintah desa telah melaksanakan amanat UU sebagaimana dijelaskan dalam Permendes No 2 Tahun 2015 (pasal 3 ayat 1 dan pasal 5 ayat 3) serta Permedagri No 114 Tahun 2014, Musrenbangdes diselenggarakan secara partisipatif, demokratis, transparan dan akuntabel dengan berdasarkan kepada hak dan kewajiban masyarakat.

Ketika pelaksanaan Musrenbangdes dilakukan sesuai prosedur yang berlaku maka kegiatan tersebut bukan seremonial belaka melainkan merupakan suatu keharusan dan kebutuhan semua elemen yang ada di desa tersebut. Musrembang desa merupakan wadah aspirasi masyarakat sekaligus merupakan syarat administrasi bagi kelengkapan dokumen 
pemerintah. Berikut ungkapan Kasi Pembangunan sekaligus Operator Desa Ibu Murtini. SH:

"Musrenbangdes selalu ada. Sejak dulu dan dilaksanakan, karena kita mengejar deadline dari pemerintah kabupaten setiap akhir bulan September semua dokumen harus sudah dilaporkan ke pemerintah kabupaten dan ke Jakarta melalui aplikasi yang di suport oleh pemerintah kabupaten."

Terlihat bahwa pelaksanaan musyawarah yang dilakukan desa Tegalarum benar-benar dilakukan sesuai dengan ketentuan. Bukti pelaksanaan dari musyawarah seperti berita acara dan daftar hadir semuanya lengkap, sehingga ketika dilakukan musrembang balai pertemuan desa penuh sesak.

Pelaksanaan Musrenbangdes tanpa ada tekanan sehingga hal ini sesuai dengan UU No 6 tahun 2014, Permendagri No 114 Tahun 2014, PP No 47 tahun 2014 dan Permendes No 2 tahun 2015 yang sudah diatur mengenai wewenang desa dalam melaksanakan kewajibannya untuk menyelenggarakan Musrenbangdes tanpa adanya intervensi dari pihak manapu.

\section{Usulan Musrembangdes}

Tahap perencanaan merupakan tahap awal dalam mengelola keuangan desa, pada tahap ini usulan-usulan pembangun desa dapat dituangkan di RPJMDes sesuai Visi dan Misi kepala desa. Usulan-usulan tadi adalah hasil musyawarah mufakat yang diselenggarakan desa. Di desa Tegalarum usulan ditetapkan di Musrenbangdes bukan hanya formalitas belaka dan dilaksanakan oleh seluruh masyarakat desa. Seperti penuturan ketua BPD mengenai usulan:

"Musrenbangdes diselenggarakan dan diikuti oleh seluruh perwakilan masyarakat desa. Usulan itu biasanya disampaikan dari masing-masing elemen masyarakat. Seperti halnya Ketua RT 01 RW I, meminta sabuk desa namun semua tenaga kerjanya dari warga setempat."

Transkrip wawancara tersebut memberikan suatu gambaran bahwa pelaksanaan Musrenbangdes dihadiri oleh seluruh elemen masyarakat dan usulan yang diusulkan ketua RT kepada kepala desa saat musyawarah memang benar-benar kebutuhan 
masyarakat . Kesadaran masyarakat desa yang merasa memiliki dan adanya kesadaran diri mengenai pembangunan desa sehingga ketua RT menjadi corong untuk mengusulkan. Masyarakat tahu bahwa setiap usulan akan dicantumkan di RPJMdes dan RKPDes. Sebuah ungkapan dari Kepala Desa Bapak Ali:

"Masyarakat datang Musrenbangdes, sampai kita kesulitan dalam membuat program prioritas karena semua usulan baik dan masuk akal ."

Sebuah uangkapan di atas memberikan sebuah jawaban bahwa masyarakat desa Tegalarum sangat peduli dengan desanya. Hal ini diperkuat pernyataan tokoh masyarakat bapak kholiq. Berikut ini ungkapan Bapak Kholiq:

"Untuk Musrenbangdes Tegal Arum, saya diundang dalam pengusulan perencanaan dan penganggaran pembangunan desa. Dana desa dibuat atau dialokasikan untuk apa saya tahu."

Sebuah ungkapan memberikan penjelasan mengenai informasi yang disampaikan kepala desa dengan tokoh masyarakat sinkron. Sebuah indikasi adanya keterbukaan yang dilakukan kepala desa kepada masyarakat mengenai usulan pembangunan desa. Proses usulan dari masyarakat yang diwakili oleh tokoh masyarakat dan aparatur menyusun usulan-usulan tersebut.

Untuk memastikan usulan-usulan sebenarnya dari masyarakat. Memverifikasi kebenaran yang telah disampaikan oleh kepala desa mengenai pernyataan beliau bahwa masyarakat diundang untuk mengikuti Musrenbangdes dan usulan dari masyarakat. Hal ini dibuktikan dalam pelaksanaan Musrenbangdes Tegalarum dilakukan secara procedural, dan hal ini sesuai dengan pasal 54 ayat 1 UU No 6/2014.

\section{Penyelenggara Musrembangdes oleh Kepala Desa dan BPD}

Salah satu kegiatan tahunan yang diselenggarakan desa adalah Musrenbangdes. Didalam Permendes dijelaskan bahwa yang menyelenggarakan Musrenbangdes BPD dan dikoordinasikan dengan kepala desa untuk pelaksanaan akan dibiayai dengan dana desa. Ketika peneliti bertanya kepada ketua BPD Bapak H. Moh. Samin. M.Si mengenai tugas dan tanggung jawab, ketua BPD menjawab sebagai berikut:

"Kalau ada musyawarah atau rapat saya dihubungi. Kalau butuh tandatangan saya ditelfon, musrembang sendiri yang menyelenggarakan kepala desa dengan saya.” 
Hasil percakapan dari sebuah wawancara menegaskan bahwa pemahaman seorang aparat mengenai tugas dan fungsi jabatan yang di emban sudah paham khusunya ketua BPD. Tugas apa saja yang diketahui dikala memegang jabatan dipemerintah desa. Jabatan yang sangat strategis dalam roda organisasi dipemerintah desa. Seperti halnya yang di alami ketua BPD desa Tegalarum mengerti apa yang harus dikerjakan dan tanggug jawab sebagai BPD.

Untuk lebih detailnya peneliti menelusuri dan menanyakan secara langsung kepada pemangku jabatan nomer satu di Desa Tegalarum mengenai penyelenggara Musrenbangdes untuk mencapai titik temu kebenaran. Sebuah penjelasan dari kepala desa Bapak Ali tentang Musrenbangdes sebagai berikut:

"Penyelenggara musrenbangdes sebenarnya adalah desa sendiri dan tempatnya dibalai desa. Untuk waktunya kapan penyenggaraan Musrenbangdes sendiri menunggu keputusan dari pihak kecamatan. Kami tidak langsung mengadakan musrenbangdes sendiri tanpa adanya intruksi sendiri dari pihak kecamatan."

Pernyataan dari ketua BPD dan kepala desa diperkuat dengan sebuah temuan dari observasi peneliti pelaksanaan penyelenggara Musrenbangdes Tegalarum sesuai arahan dari kecamatan. Pihak kecamatanlah yang menentukan pelaksanaan Musrenbangdes dengan menghubungi kepala desa untuk disebarkan kepada aparat desa.

Sebagaimana dijelaskan dalam Permendes No 2 Tahun 2015 pasal 5 ayat 1 Musrenbangdes diselenggarakan oleh BPD yang difasilitasi oleh Pemerintah Desa. Dan UU desa No 6 Tahun 2016 pasal 55 fungsi BPD adalah membahasa dan menyepakati Eancangan Peraturan Desa bersama Kepala Desa, menampung dan menyalurkan aspirasi masyarakat desa dan melakukan pengawasan kinerja Kepala Desa. Ketika BPD bekerja optimal dalam menyerap aspirasi masyarakat untuk perencanaan pembangunan desa maka proses pembangunan desa akan berjalan lancar.

\section{Proses Penyusunan Dokumen Musrenbang}

\section{Proses Penyusun Dokumen Perencanaan}

Setiap tahun desa membuat suatu dokumen perencanaan RKPDes dan APBDes serta RAB dalam melaksanakan suatu kegiatan. Pada saat peneliti menanyakan 
dokumen-dokumen perencanaan seperti RPJM desa, RKP desa, dan APBDesa kepada kepala desa, jawabannya adalah ada di Kantor Kepala Desa. Berikut ungkapan kepala desa Bapak Ali:

"Kalau dokumen-dokumen RPJMDes, RKPDes, dan APBDes, ada dikantor. Yang nyusun dokumen itu saya suruh ke carek dan Kasi Pembangunan yang mahir komputer. Datanya lengkap ada di Murtini. Coba tanya kesana saja."

Ungkapan tersebut mengisyaratkan bahwa kepala desa mengerti dan tahu apa yang dibangun selama 6 tahun kedepan dan estimasi biaya yang keluar untuk pembangunan desa setiap tahunnya dengan mengacu RAB atau APBDes. Pernyataan dari kepala desa di atas menarik untuk ditelusuri untuk mencari kebenaran. Rasa penasaran tentang pernyataan kepala desa membuat peneliti melakukan konfirmasi terhadap praktik penyusunan RPJMDes, RKPDes, dan APBDes kepada sekretaris desa. Pencarian kebenaran untuk memverifikasi Pengakuan dari sekretaris desa menjawab penasaran peneliti. Berikut penuturan mereka berdua:

Sekdes Bapak H. Mashudi mengungkapkan:

"Kalau dokumen RPJMDes, RKPDes, dan APBDes saya dan bu Murtini yang buat, kalau enggak percaya coba Tanya beliau."

Pencarian kebenaran dengan mengkroscek pengakuan kepala desa dan sekretaris desa diperkuat oleh ungkapan Kasi Pembangunan Ibu Hj. Murtini:

"Yang nyusun dokumen RPJMDes, RKPDes, dan APBDes itu kepala desa dan aparat desa. Aparat desa tahu tentang dokumen perencanaan. Tugas terberat saya memperbaiki dan membuat SPJ dari keluarnya anggaran dan mencocokkan bukti-bukti."

Berdasarkan pengakuan perangkat desa tentang dokumen perencanaan dibuktikan dengan peneliti menemukan dokumen tersebut ada di kantor balai desa. Hasil informasi dari pengakuan aparatur desa sinkron dengan temuan bukti adanya dokumen perencanaan yang ada di kantor balai desa. Hal ini sesuai dengan penerapan UU desa nomor 6 tahun 2014. Berdasarkan penjelasan UU No 113 dan 114 tahun 2014, desa Tegalarum melakukan prinsip yang benar. 


\section{De Facto dan De Jure Koordinator Pengelolaan Keuangan Desa}

Sekretaris Desa dalam kegiatan pengelolaan keuangan berfungsi pada tahap perencanaan dan pelaksanaan. Kasus yang menarik di desa Tegalarum kosongnya jabatan sekdes. Sekretaris Desa yang sekarang adalah pelaksana tugas yang digaji dari anggaran. Hubungan sekdes dengan kepala desa layaknya suami dan istri yang harmonis. Berikut ungkapan Kepala Desa Bapak Ali:

"Hubungan kepala desa dengan carek itu bagaikan suami sama istri. Kalau tidak ada singkronisasi maka roda pemerintahan ini tidak akan berjalan.”

Cuplikan wawancara ini memberikan gambaran bahwa hubungan harmonis dan singkronisasi sangat diperlukan dalam roda pemerintahan desa. Ketika ketidak cocokan antara salah satu pihak aparat desa dapat menimbulkan lambatnya pergerakan kinerja didalamnya.

Kebiasaan dalam pemerintah desa adalah mengambil aparat desa dari keluarga sendiri. Sebuah uraian dari kepala desa Tegalarum Bapak Ali:

"Kalau bisa pemilihan aparat desa khusunya sekdes jangan dari keluarga sendir. Ketika keluarga sendiri yang dijadikan sekdes, ini termasuk dari KKN..”

Ungkapan menarik untuk di pahami lebih dalam. Pencapaian yang ingin dicapai untuk menjadikan desa good governece akan terhalang jika ada KKN.

\section{Penetapan APBDes dan Peraturan Desa}

\section{Pelaksanaan Penetapan}

Dokumen-dokumen perencanaan yang sudah disusun oleh pemerintah desa harus ditetapkan melalui peraturan desa. Tanpa adanya penetapan dan ditandatangani oleh BPD dan kepala desa dana desa tidak akan cair. Di desa Tegalarum selalu tepat waktu yakni pada bulan September dalam penetapan APBDes. Namun pencairan dana dari pemerintah kabupaten tidak pernah tepat waktu. Sebuah uangkapan dari Kepala Desa Bapak Ali mengenai hal ini sebagai berikut: 
"Penetapan anggaran selalu tepat waktu walaupun menunggu pagu indikatif anggaran pemerintah yang akan diturunkan. Lha wong, penetapan tepat waktu pencairannya pasti terlambat. Sehingga kita harus cari uang untuk pembangunan yang telah direncanakan, sebagai contoh dana desa tahun 2018, yahap III kemaren aja cair tanggal 15 desember 2018, apa kita tidak oyak-oyak untuk membuat LPJ khan semua bukti pengeluaran dan uang keluar harus cocok...:Pembangunan desa ngutang dulu sehingga proyek pembangunan akan tumpang tindih dan mengejar target."

Sebuah pernyataan kepala desa memberikan sedikit gambaran mengenai keterlambatan pencairan dana desa. Ada beberapa faktor yang menyebabkan terlambatnya pencairan dana desa. Sebuah indikasi yang disengaja oleh pihak pemerintah daerah dalam menangguhkan penyampaian pagu indikatif dan selalu berdalih belum adanya surat permohonan pencairan. Salah satu penuturan Tokoh masyarakat Bapak Suryo sebagai berikut:

"saya sering mendengar bahwa banyak desa yang terlambat dalam menetapkan APBDes meskipun penyusunan perencanaan dan dokumennya sudah selesai, sampai-sampai tiga sampai empat bulan. Menurut saya ada beberapa faktor terlambatnya penetapan. Pertama, pemerintah daerah tidak memberikan informasi jumlah pagu anggaran yang akan cair dengan cepat sehingga pemerintah desa getar-getir dalam menetapkan anggaran. Takutnya yang dianggarkan desa tidak sama dengan pagu anggaran yang ditetapkan pemerintah daerah sehingga takut menimbulkan SPJ tidak sama. Kedua, ada indikasi pemerintah daerah memang sengaja menyimpan dana desa yang sudah cair di bank agar bisa berbunga. Bunganya bisa diambil oleh oknum-oknum yang ada dipemerintah daerah.”

Faktor lain yang disampaikan tokoh masyarakat bahwa ada kesengajaan dana yang cair dari pusat tidak langsung ditransfer ke rekening desa. Kasus ini memberikan makna tidak ada sinkronisasi antara pemerintah desa sampai pemerintah daerah atau mungkin pemerintah pusat. Semakin banyak pertanyaan-pertanyaan untuk lini sektor pemerintah yang menumpuk dan tidak terselesaikan. Lubang-lubang menyempatkan oknum untuk 
berbuat menikung demi memperkaya diri sendiri. Hal ini tidak sesaui dengan Pasal 35 Permendagri No 114 Tahun 2014 tentang perencanaan dan penganggaran dana desa:

"Kepala Desa mendapatkan data dan informasi dari kabupaten/kota tentang pagu indikatif Desa.Data dan informasi diterima kepala Desa dari kabupaten/kota paling lambat bulan Juli setiap tahun berjalan."

Terlambatnya penetapan APBDes sudah masalah klasik yang tidak kunjung selesai. Bukan pemerintah desa saja yang mengalami hal serupa itu, melainkan pemerintah daerah yang SDMnya sudah lulusan sarjana juga sama. Wangi dan Ritonga (2010), Subechan at al., (2014), Sutaryo dan Carolina (2014).

\section{Sinergi Kepala Desa dan BPD}

Dokumen yang terpenting dalam perencanaan adalah APBDes karena berhubungan dengan anggaran yang direncanakan guna pembangunan desa. Hal ini telah sesaui dengan desa Tegalarum tentang mekanisme pembuatan dokumen APBDes. Pihak aparat desa terutama kepala desa sangat menghetahui berapa nominal dan rincian pembanguanan yang ada di dokumen dan juga aparat yang lain. Masing-masing pembangunan yang sudah direncanakan sudah ada yang ngurusin termasuk material yang akan dibutuhkan. Berikut ini penjelasan Kepala Desa Bapak Ali:

"Rencana anggaran pembangunan desa itu semua masyarakat ikut terlibat dan yang menghitung kita semua. Contohnya pembangunan jembatan, setelah dihitung kita panggil semua warga yang berkaitan, contohnya adalah apabila kita membeli material, kita panggil semua toko material yang ada di desa dan kita tenderkan secara terbuka siapa nanti yang akan menyuplai material pembangunan jembatan tersebut, kalau tenaga kerja kita ambil dari daerah tersebut, sehingga warga saya, tidak hanya menikmati tapi juga ikut merasakan, kareana pembangunan fisik senilai Rp 70 juta rupiah saja harus ditenderkan."

Sebuah realitas yang harmonis kepala desa tidak hanya memimpin namun juga memikirkan masyarakatnya. Anggaran desa yang sudah dibuat selalu dimusyawarahkan dengan BPD dan disahkan atau ditetapkan sebagai acuan pembangunan selama setahun kedepan. Aparatur desa semua yang mengurusi tentang pembuatan dan penyusunan 
dokumen perencanaan dan penganggaran dana desa. Tugas-tugas penting pemerintah desa sudah terselesaikan sehingga aparatur desa memperbaiki bila terjadi kesalahan dengan bantuan dari pihak kecamatan. Pernyataan ini diperkuat sebagaimana dijelaskan oleh ketua BPD sebagai berikut:

"Saya tahu mengenai masalah anggaran. Dan saya selalu diajak komunikasi dan koordinasi dengan kepala desa, terlebih saya juga orang pemerintahan jadi tahu mekanismenya,"

Hasil transkip wawancara diatas memberikan penjelasan bahwa tugas dan tanggung jawab sebagai aparat desa berjalan sebagaimana mestiya. Hal ini sesuai dengan UU No 6 Tahun 2014 mengatur fungsi dan tanggung jawab dari setiap aparat desa, dan Permendagri No 113 Tahun 2014 menyebutkan bahwa "Rancangan peraturan Desa tentang APBDes disampaikan oleh Kepala Desa kepada Badan Permusyawaratan Desa untuk dibahas dan disepakati bersama."

\section{Transparansi APBDes}

Transparansi dana desa yang sudah cair harus diinformasikan. Jika transparansi tidak dilaksanakan maka dampak negatif dari masyarakat akan mengatakan bahwa aparatur desa sudah menggelapkan dana desa tersebut. Sebuah pernyataan dari tokoh masyarakat Bapak Kholiq tentang rencana kerja desa dan anggaran belanja desa, menarik untuk didengarkan. Berikut ini penjelasannya:

"Kalau masalah anggaran desa ini saya memang mengetahui. Berapa jumlah dana dari pemerintah dan peruntukannya untuk apa saja tahu. Untuk masalah ini, semua masyarakat banyak yang tahu, tapi tidak mungkin setiap individu masyarat menghetahui maka persepsi buruk masyarakat pasti ada Jenengane wae duwit, sopo sing ora gelem?.”

Hasil wawancara memberikan refleksi adanya transparansi anggaran biaya dana desa. Penyampaian bapak kholiq meberikan isyarat bahwa menjadi pemimpin sangatlah sulit untuk objektif dan masalah anggaran sering kali menjadi pemicu mengapa sesorang bisa berbohong dan tidak transparasnsi kepada khalayak umum. 
Selama pengamatan peneliti dalam melakukan observasi dilapangan belum sepenuhnya ada bentuk transparansi yang diberikan oleh kepala desa Tegalsrum kepada masyarakat. Seharusnya pihak pemerintah desa menyebarkan informasi tentang rencana kerja dan dipaparkan pada lembaran APBDes dan menyebarkan informasi tersebut kepada masyarakat atau membuat banner yang ditaruh di balai desa agar masyarakat tahu bahwa desa mendapatkan anggaran berapa kemudian dibuatkan untuk apa saja. Selama ini sejak dimulainya implementasi UU Desa No 6 Tahun 2014 sampai sekarang belum memampangkan anggaran desa dibalai desa. Perlunya evaluasi dari pihak internal dan ekternal mengenai transparansi desa harus lebih ditingkatkan agar kemanjuan dan kemandirin desa dapat tercapai.

Masalah yang sederhana namun bertentangan dengan prinsip anggaran di sektor publik yang mengharuskasn untuk transparansi anggaran. UU No 14 tahun 2008 tentang keterbukaan informasi public yang mengatur kewajiban badan public agar mengumumkan informasi baik, kinerja, kegiatan dan laporan keuangan. Sedangkan perundang-undangan desa juga diatur mengenai transparansi anggaran khusunya tentang UU No 6 tahun 2014 menjelaskan bahwa:

"melaksanakan prinsip tata Pemerintahan Desa yang akuntabel, transparan, profesional, efektif dan efisien, bersih, serta bebas dari kolusi, korupsi, dan nepotisme"

Didunia akademisi sering sekali dibahas di mata kuliah akuntansi sektor publik mengenai masalah anggaran yang harus transparan. Ketika melihat keterbukaan yang dilakukan oleh pemerintah desa sudah terpenuhi walaupun belum maksimal.

\section{Kesimpulan}

Penelitian ini diambil beberapa simpulan. Untuk gambaran proses perencanaan dan penganggaran APBDes di desa Tegalarum memilliki tiga poin penting. Kesimpulan penelitian berdasarkan temuan peneliti di lapangan mencakup beberapa hal yaitu, pelaksanaan Musrenbangdes dilakukan sesuai ketentuan dan bukan semata-mata ceremonial belaka. Usulan perencanaan yang tidak terlaksana pada pelaksanna APBDes di prioritaskan pada Musrembang tahun selanjutnya. 
Proses penetapan telah sesuai dengan ketentuan dan waktu yang telah ditentukan namun, proses pencairan Dana Desa dari Pemerintah Kabupaten selalu terlambat. Temuan lainnya yang cukup menarik adalah "otonomi politik" di tingkat pemerintah desa yang dipegang dan dikendalikan oleh kepala desa berdampak terhadap manajemen pengelolaan keuangan desa. Kepala desa berperan sebagai Kuasa Pengguna Anggaran dan proses -proses teknis lainnya.

\section{Keterbatasan dan Saran}

Keterbatasan penelitian ini yaitu peneliti tidak mewawancarai seluruh aparat desa dan anggota BPD. Tidak bisa mengkonfirmasi kebenaran kepada pihak pemerintah daerah tentang kebenaran masalah adanya potongan mengenai turunnya dana desa dan terlambatnya pengumuman pagu indikatif anggaran karena keterbatasan waktu.

Peneliti memberikan saran kepada beberapa pihak atas penelitian ini.

1. Pemerintah Pusat

a. Diharapkan BPK sudah bisa turun di seluruh desa untuk melakukan pemeriksaan lebih intensif lagi;

b. Untuk pemerintah pusat melakukan penyaluran Dana Desa tepat waktu.

2. Pemerintah Daerah dan Kecamatan

a. Diharapkan melakukan pengawasan yang rutin terkait perencanaan dan penganggaran desa;

b. Memberikan banyak sosialisasi terkait perencanaan dan penganggaran khususnya pembuatan dokumen perencanaan kepada Pemerintah Desa, sosialisasi kepada BPD tentang tatacara teknis pengawasan, dan sosialisasi kepada masyarakat desa Tegalrum.

3. Pemerintah Desa Tegalarum yaitu:

a. Meningkatkan sistem pengendalian internal Pemerintah Tegalarum.

b. Meningkatkan transparansi dalam menggunakan keuangan desa seperti memampang APBDes di papan pengumuman balai desa.

4. Saran untuk penelitian selanjutnya untuk meneliti faktor-faktor yang menghambat terlambatnya penetapan APBDes dan cara pengawasan yang dilakukan dari pemerintah daerah, kecamatan (ekternal) dan internal pemerintah desa dalam pengelolaan keuangan desa. 


\section{DAFTAR PUSTAKA}

Agusti, Restu. 2012. Pengaruh Partisipasi Penyusunan Anggaran Terhadap Kinerja Aparatur Pemerintah Daerah Dengan Dimoderasi Oleh Variabel Desentralisasi Dan Budaya Organisasi (Studi Kasus Pada Pemerintah Kabupaten Bengkalis). Jurnal Ekonomi Fakultas Ekonomi Universitas Riau Volume 20, Nomor 3.

Anggraini, Imwldha dan Redy S., Achdiar. 2011. Pengaruh Komitmen Organisasi dan Gaya Kepemimpinan Terhadap Hubungan Partisipasi Anggaran dan Kinerja Aparat Pemerintah Daerah. Jurnal Akuntasi Multiparadigma Vol 2, No 2 Hal. 186-368.

Burin, Ferdinandus Diri et, al. 2015. Analisis Konsistensi Perencanaan Dan Penganggaran Daerah. Jurnal Ekonomika-Bisnis Vol. 6 No. 2 Hal 177-188.

Dachliyati. 2015. Mengungkap Fenomena Fraud Atas Pengelolaan Dana Desa. Karya Ilmiah. Bangkalan: Program Pascasarjana Akuntansi Universitas Trunojoyo Madura.

Dewanti, Elsa Dwi Wahyu et., al. 2016. Analisis Perencanaan Pengelolaan Keuangan Desa Di Desa Boreng (Studi Kasus Pada Desa Boreng Kecamatan Lumajang Kabupaten Lumajang). Artikel Ilmiah Mahasiswa Akuntansi, Fakultas Ekonomi, Universitas Jember (UNEJ).

Friyanty, Ita. 2016. Faktor- Faktor Yang Mempengaruhi Kinerja Manajerial Aparat Pemerintahan (Studi KasusPemerintah Daerah Indramayu). Jurnal Tekun Universitas Mercu Buana Volume VII, No.01,Hal: 62 -79.

Furqani, Astri. 2010. Pengelolaan Keuangan Desa Dalam Mewujudkan Good Governance (Studi Pada Pemerintahan Desa Kalimo'ok Kec. Kalianget Kab. Sumenep). Karya Ilmiah. Surabaya: Program Pascasarjana UPN "Veteran".

Hidayati, Sri et., al. 2015. Pengaruh Partisipasi Anggaran, Pemahaman Penyusun Rencana Kerja Anggaran (Rka) Dan Asimetri Informasi Terhadap Efektifitas Anggaran Skpd Di Pemerintah Kota Mataram. Jurnal InFestasi Universitas Mataram Vol. 11, No.1, Hal. 93 - 111.

Indriani, Mirna dan Nadirsyah. 2014. Interaksi Antara Budgetary Participation Dan Karakteristik Sistem Akuntansi Manajemen Terhadap Kinerja Manajerial: Survei Pada Organisasi Pemerintah Daerah. Jurnal Fakultas Ekonomi Universitas Syiah Kuala.

Modesianne R.Y, Elitrisiana. 2016. Konsistensi Program Rencana Pembangunan Jangka Menengah Daerah Tahun 2013-2017 Dengan Anggaran Pendapatan Belanja Daerah Di Provinsi Dki Jakarta. Jurnal Pembangunan Daerah Volume 4.

Moleong, Lexy J. 2016. Metodologi Penelitian Kualitatif (Edisi Revisi). Jakarta: PT Remaja Rosdakarya. 
Republik Indonesia. Peraturan Menteri Dalam Negeri Nomor 66 Tahun 2007 Tentang Pedoman Pembangunan Desa.

Republik Indonesia. Undang-Undang Nomor 14 Tahun 2008 Tentang keterbukaan Informasi Publik.

Republik Indonesia. Peraturan Pemerintah Nomor 60 Tahun 2014 Tentang Dana Desa yang Bersumber dari Anggaran Pendapatan dan Belanja Negara.

Republik Indonesia. Undang-Undang Nomor 6 Tahun 2014 Tentang Desa.

Republik Indonesia. Peraturan Pemerintah Nomor 43 Tahun 2014 Tentang Peraturan Pelaksanaan Undang-Undang Nomor 6 Tahun 2014 Tentang Desa.

Republik Indonesia. Peraturan Pemerintah Nomor 47 Tahun 2015 Tentang Peraturan Pelaksanaan Undang-Undang Nomor 6 Tahun 2014 Tentang Desa

Republik Indonesia. Peraturan Menteri Dalam Negeri Nomor 113 Tahun 2014 Tentang Pengelolaan Keuangan Desa.

Republik Indonesia. Peraturan Menteri Dalam Negeri Nomor 114 Tahun 2014 Tentang Pedoman Pembangunan Desa.

Republik Indonesia. Peraturan Menteri Desa Nomor 2 Tahun 2015 Tentang Pedoman Tata Tertib dan Mekanisme Pengambilan Keputusan Musyawarah Desa.

Republik Indonesia. Peraturan Pemerintah Nomor 22 Tahun 2015 Tentang Perubahan atas Peraturan Pemerintah Nomor 60 Tahun 2014 Tentang Dana Desa yang Bersumber dari Anggaran Pendapatan dan Belanja Negara.

Republik Indonesia. Peraturan Menteri Desa Nomor 21 Tahun 2015 Tentang Penetapan Prioritas Pembangunan Dana Desa Tahun 2016.

Republik Indonesia. Peraturan Menteri Desa Nomor 1 Tahun 2015 Tentang Pedoman Kewenangan Berdasarkan Hak Asal Usul dan Kewenangan Lokal Berskala Desa.

Rohimanto. 2015. Fenomena Pengelolaan Keuangan Desa (Studi pada Pemerintah Desa Banyuajuh, Kecamatan Kamal, Kabupaten Bangkalan). Karya Ilmiah. Bangkalan: Program Sarjana Universitas Trunojoyo Madura.

Rohmah, Nur Faizatun.2015. Pengelolaan Dana Desa Di Tahun Pertama: Kentalnya Mindset Kepala Desa Sebagai Si "Raja Kecil”. Karya Ilmiah. Bangkalan: Program Sarjana Universitas Trunojoyo Madura.

Sopanah. 2012. Ceremonial Budgeting Dalam Perencanaan Penganggaran Daerah: Sebuah Keindahan yang Menipu. Jurnal Widyagama Malang. 
Tuasikal, Askam. 2010. Fenomenologis Perencanaan Dan Penganggaran Pemerintah Daerah. Jurnal Akuntansi Universitas Jember.

Wangi, Chitra Ariesta Pandan dan Ritonga, Irwan Taufiq. 2010. Identifikasi Fakto-Faktor Penyebab Terjadinya Keterlambatan Dalam Penyusunan APBD (Studi Kasus Kabupaten Rejang Lebong Tahun Anggaran 2008 -2010). Simposium Nasional Akuntansi 13 purwokerto.

(http://m.republika.co.id/berita/nasional/umum/15/05/16/nog8bu-dana-desa-dijamin-rp1-miliar-per- desa-pada-2016, diakses 13 Juni 2016) 
Majalah Ilmiah Solusi

Vol. 17, No. 2 April 2019

ISSN : 1412-5331

" Halaman ini sengaja di kosongkan " 